\title{
MENAKAR MODEL PENGEMBANGAN KURIKULUM DI MADRASAH
}

\author{
Amru Almu'tasim \\ Institut Agama Islam Uluwiyah Mojokerto \\ e-mail: amru.dosen@gmail.com
}

\begin{abstract}
Abstrak
Madrasah sebagai salah satu lembaga pendidikan Islam dalam proses pengembangan kurikulum harus didasarkan pada landasan pengembangan kurikulum yang ada. Penting untuk diperhatikan dalam melihat berbagai percakapan, kurikulum di Madrasah dianggap memiliki peran yang sangat besar karena di dalamnya terdapat muatan moral agama yang menjadikan manusia / peserta didik berakhlaqul karimah dan dididik sesuai dengan nilainilai Islam. Karena pada dasarnya perubahan kurikulum mengarah pada pengembangan kurikulum untuk mencapai tujuan pendidikan yang diharapkan karena berbagai pengaruh positif yang datang dari luar atau dari dalam dirinya sendiri, dengan harapan bahwa peserta didik dapat menghadapi masa depan mereka dengan baik. Jadi esensi pengembangan kurikulum itu sendiri adalah proses identifikasi, analisis, sintesis, evaluasi, pengambilan keputusan dan penciptaan elemen kurikulum. Agar proses pengembangan kurikulum dapat bekerja secara efektif dan efisien, pengembang kurikulum harus bekerja pada prinsip pengembangan kurikulum.
\end{abstract}

Kata Kunci: Madrasah, Kurikulum, Pendidikan Islam

\begin{abstract}
Madrasah as one of the Islamic educational institutions in the process of curriculum development should be based on the foundations of curriculum development that exist. It is important to note seeing in various conversations, the curriculum in Madrasah is considered to have a very big role because in it there are religious moral charges that make human / learners berakhlaqul karimah and educated in accordance with Islamic values. Because basically curriculum changes lead to curriculum development in order to achieve the expected educational objectives because of the various positive influences that come from outside or from within itself, in the hope that learners can face their future well. So the essence of curriculum development itself is the process of identification, analysis, synthesis, evaluation, decision making and the creation of curriculum elements. In order for the curriculum development process to work effectively and efficiently, curriculum developers must work on curriculum development principles.
\end{abstract}

Keywords: Madrasah,Curriculum, Islamic Education

\section{PENDAHULUAN}

Secara etimologis, kurikulum berasal dari bahasa Yunani, yaitu carier yang artinya pelari dan curare yang berarti tempat berpacu. Jadi, istilah kurikulum berasal dari dunia 
olah raga pada zaman Romawi Kuno di Yunani, yang mengandung pengertian suatu jarak yang harus ditempuh oleh pelari dari garis start sampai garis finish. Dalam bahasa Arab, kata kurikulum bisa diungkapkan dengan manhaj yang berarti jalan yang dilalui oleh manusia pada berbagai bidang kehidupan. Sedangkan kurikulum pendidikan (manhaj aldirasah) dalam qamus Tarbiyah adalah seperangkat perencanaan dan media yang dijadikan acuan oleh lembaga pendidikan dalam mewujudkan tujuan-tujuan pendidikan. ${ }^{1}$

Secara terminologi kurikulum adalah seperangkat rencana dan pengaturan mengenai tujuan, isi, dan bahan pelajaran serta cara yang digunakan sebagai pedoman penyelenggaraan kegiatan pembelajaran dalam mencapai tujuan pendidikan tertentu. ${ }^{2}$ Kurikulum sendiri sebagai sebuah kata yang diidentikkan dengan pendidikan memiliki makna yang sangat beragam sesuai dengan keberagaman latar belakang orang yang menekuni teori pendidikan. Menurut kajian Scubert, keragaman makna kurikulum dirangkum dalam delapan wajah kurikulum atau yang dia sebut sebagai "the images of curriculum”, yaitu: Kurikulum bermakna mata pelajaran (content or subject matter); kurikulum bermakna program atau aktivitas terencana (program or planned activities); kurikulum bermakna hasil belajar yang diharapkan (intended learning outcomes); kurikulum bermakna reproduksi budaya cultural reproduction); kurikulum bermakna pengalaman (experience); kurikulum bermakna tugas dan konsep tertentu (discrete task and concept); kurikulum bermakna agenda rekonstruksi sosial (agenda for social reconstruction); dan kurikulum bermakna track yang dilalui (curere). ${ }^{3}$

Dari beberapa pengertian di atas dapat disimpulkan kurikulum adalah suatu program pendidikan yang di rencanakan, di programkan, dan di rancang sedemikian rupa secara sistematis yang berisi bahan ajar serta pengalaman belajar sehingga dalam program pendidikan memiliki arah dan tujuan yang akan dicapai dan dari hasil yang dicapai kita dapat merevisi ulang dan mengembangkan program pendidikan untuk memperoleh hasil yang lebih baik dari sebelumnya sehingga suatu kurikulum pembelajaran dapat dikatakan selalu berubah-ubah sesuai dengan kebutuhan dan perkembangan pendidikan.

Sedangkan pengembangan kurikulum dapat diartikan sebagai suatu proses perencanaan dan penyusunan kurikulum yang dilakukan oleh pengembang kurikulum agar kurikulum yang dihasilkan dapat menjadi bahan ajar dan acuan yang digunakan untuk

\footnotetext{
${ }^{1}$ Ramayulis, Ilmu Pendidikan Islam, (Jakarta: Kalam Mulia, 2008), hlm 150

${ }^{2}$ UU No. 20 tahun 2003, Sistem Pendidikan Nasional, (Jakarta: Depag, 2003)

${ }^{3}$ W. H. Schubert, Curriculum: Perspective, Paradigm and Possibility, (New York: MacMillan, 1986), hlm. 26 - 33
} 
mencapai tujuan pendidikan nasional. ${ }^{4}$ Penulis sendiri dapat mengartikan pengembangan kurikulum merupakan prosedur umum dalam kegiatan mendesain (designing), menerapkan (implementation), dan mengevaluasi (evaluation) suatu kurikulum. Dalam pengembangan kurikulum banyak pihak-pihak yang harus berpartisipasi diantaranya adalah administrator pendidikan, para ahli pendidikan yang ahli dalam kurikulum, ahli dalam bidang ilmu pengetahuan, guru dan orangtua, tokoh masyarakat, dari pihak tersebut yang secara terus menerus menerus turut terlibat dalam pengembangan kurikulum agar berjalan sesuai dengan yang direncanakan. ${ }^{5}$

\section{PEMBAHASAN}

Fred Percival dan Henry Ellington (1984) mengemukakan bahwa pengembangan kurikulum adalah pengembangan proses perencanaan, validasi, implementasi, dan evaluasi kurikulum. ${ }^{6}$ Sehingga dalam proses pengembangan kurikulum setidaknya harus berdasarkan pada prinsp-prinsip di bawah ini, yaitu:

a. Prinsip Peningkatan Keimanan dan Ketakwaan, Budi Pekerti Luhur, dan Nilainilai Budaya. Keyakinan dan nilai-nilai yang dianut oleh masyarakat berpengaruh pada sikap dan arti kehidupannnya. Keimanan dan ketakwaan, budi pekerti luhur dan nilai-nilai budaya perlu digali, dipahami, dan diamalkan oleh peserta didik dalam kehidupan sehari-hari. ${ }^{7}$

b. Berpusat pada Potensi, Perkembangan, Kebutuhan dan kepentingan Peserta Didik serta tuntutan Lingkungan. Hal ini dimaksudkan agar peserta didik menjadi manusia yang beriman dan bertakwa kepada Tuhan Yang Maha Esa, berakhlak mulia, sehat, berilmu, cakap, kreatif, mandiri, dan menjadi warga Negara yang demokratis dan tanggung jawab. ${ }^{8}$

c. Prinsip Keseimbangan antara Etika, Logika, Estetika dan Kinestetika. Kurikulum hendaknya menaruh perhatian terhadap siswa agar mampu menjaga keseimbangan dalam proses dan pengalaman belajar yang meliputi etika, logoka,

${ }^{4}$ Suparlan, Tanya Jawab Pengembangan Kurikulum dan Materi Pembelajaran, (Jakarta: Bumi Aksara, 2011) hlm 79

${ }^{5}$ Nana Syaodih Sukmadinata, Pengembangan Kurikulum teori dan Praktek, (Bandung: PT Remaja Rosda Karya, 2007) Hlm 155.

6 Oemar Hamalik, Dasar-dasar Pengembangan Kurikulum, (Bandung: PT Remaja Rosdakarya, 2013), hlm. 194

${ }^{7}$ Muhaimin dkk, Pengembangan Kurikulum Berbasis Kompetensi di Perguruan Tinggi Agama Islam (Yogyakarta: Pustaka Pelajar, 2005), hlm 61

${ }_{8}$ Muhaimin dkk, Pengembangan Model Kurikulum Tingkat Satuan Pendidikan (KTSP) pada Sekolah dan Madrasah. (Jakarta: Rajawali Pers, 2008), hlm 21-22. 
estetika, dan kinestetika, sehingga siswa akan menjadi seseorang yang terhormat, cerdas, rasional, dan unggul. ${ }^{9}$

d. Prinsip Penguatan Integritas Nasional. Prinsip ini dimaksudkan untuk menanamkan kesadaran bahwa Indonesia adalah Negara yang majemuk, tetapi keanekaragaman itu tidak boleh membuat perpecahan, karena walaupun berbeda tetap satu jua (Bhineka Tunggal Ika). ${ }^{10}$

e. Prinsip Pengetahuan dan Teknologi Informasi. Kurikulum dikembangkan atas dasar kesadaran bahwa ilmu pengetahuan dan teknologi terus berkembang, sehingga kurikulum mendorong siswa untuk mampu mengikuti dan memanfaatkan secara tepat ilmu pengetahuan dan teknologi tersebut agar siswa memiliki kemampuan untuk berpikir dan belajar dengan baik. ${ }^{11}$

f. Prinsip Pengembangan Keterampilan Hidup. Prinsip ini mengembangkan 4 keterampilan yang harus dimiliki oleh setiap peserta didik yang sesuai dengan kebutuhan di lingkungan sekitarnya yaitu keterampilan diri (personal skill), keterampilan berfikir rasional (thinking skills), keterampilan akademik (academic skills), keterampilan vocasional (vocational skills). Dengan keterampilan tersebut, setelah siwa tersebut lulus sekolah dapat mempertahankan hidupnya sesuai dengan pilihan masing-masing individu. ${ }^{12}$

g. Prinsip Pilar Pendidikan. Pilar pendidikan yang dijadikan prinsip pengembanga kurikulum di madrasah ada empat yaitu: learning to know (belajar untuk memahami), learning to do (kemampuan untuk berbuat), learning to be (belajar untuk menjadi diri sendiri), dan learning to live together (belajar untuk hidup dalam kebersamaan). ${ }^{13}$

h. Prinsip Kontinuitas (berkesinambungan). Kurikulum disusun secara berkesinambungan artinya bagian-bagian, aspek-aspek, materi, dan bahan kajian disusun secara berurutan. Oleh karena itu, pengalaman belajar yang disediakan

\footnotetext{
9 Muhammad Zaini, Pengembangan Kurikulum Konsep Implementasi Evaluasi dan Inovasi. (Yogyakarta: Teras, 2009). Hlm 112.

10 Muhammad Zaini, Pengembangan Kurikulum Konsep Implementasi Evaluasi dan Inovasi, hlm. 112

${ }^{11}$ Muhaimin dkk, Pengembangan Model Kurikulum Tingkat Satuan Pendidikan (KTSP) pada Sekolah dan Madrasah, .........., hlm. 22

12 Muhammad Zaini, Pengembangan Kurikulum Konsep Implementasi Evaluasi dan Inovasi, hlm. 117

${ }_{13}$ http://www.bintangbangsaku.com/content/prinsip-prinsip-pengembangan-kurikulum-tingkatsatuan-pendidikan, diakses pada tanggal 10 Agustus 2017
} 
kurikulum harus memperhatikan kesinambungan (antar kelas, antar jenjang pendidikan, antara jenjang pendidikan dengan jenis pekerjaan). ${ }^{14}$

i. Prinsip Belajar Sepanjang Hayat. Kurikulum di madrasah diarahkan kepada pengembangan, pembudayaan,dan pemberdayaan peserta didik yang berlangsung sepanjang hayat. Kurikulum mencerminkan keterkaitan unsure-unsur pendidikan formal, informal dan nonformal dengan memperhatikan kondisi dan tuntut lingkungan yang selalu berkembang. ${ }^{15}$

Selain beberapa prinsip khusus diatas, juga ada beberapa prinsip umum dalam pengembangan kurikulum. Pertama, yaitu prinsip relevansi, baik relevan ke luar maupun di dalam kurikulum itu sendiri. Artinya kurikulum tersebut hendaknya sesuai antara komponen-komponen kurikulum didalamnya, baik dari tujuan, isi, proses dan peniliaian selain itu hendaknya juga relevan dengan tuntutan, kebutuhan dan perkembangan masyarakat. Kedua, yaitu prinsip fleksibilitas, dimana kurikulum tersebut dapat digunakan untuk semua anak yang memiliki latar belakang dan kemampuan yang berbeda. ${ }^{16}$

Ketiga, yaitu prinsip kontinuitas, artinya kurikulum hendaknya berkesinambungan antara satu tingkat kelas, dengan kelas lainnya, antara satu jenjang pendidikan dengan jenjang pendidikan lainnya. Keempat, yaitu prinsip praktis, yang mengarah pada efisiensi. Karena betapapun bagus dan idealnya suatu kurikulum namun jika menuntut keahliankeahlian dan peralatan yang sangat khusus dan mahal pula biayanya, maka kurikulum tersebut tidak praktis dan sukar dilaksanakan. Kelima, yaitu prinsip efektivitas, walaupun kurikulum tersebut harus murah, sederhana dan mudah namun keberhasilannya tetap harus diperhatikan.

\section{A. Landasan Pengembangan Kurikulum}

Selain dari sembilan prinsip di atas, dalam proses pengembangan kurikulum, ada beberapa landasan yang harus diperhatikan dan dipertimbangkan oleh para pengembang kurikulum ketika hendak mengembangkan atau merencanakan suatu kurikulum lembaga pendidikan. ${ }^{17}$ Landasan-landasan tersebut antara lain :

a. Landasan Agama. Dalam mengembangkan kurikulum sebaiknya berlandaskan pada Pancasila terutama sila ke satu "Ketuhanan Yang Maha Esa". Di Indonesia menyatakan bahwa kepercayaan dan ketakwaan terhadap Tuhan Yang Maha Esa

\footnotetext{
${ }^{14}$ Oemar Hamalik, Kurikulum dan Pembelajaran. (Bandung: Bumi Aksara, 2001), hlm 32.

${ }^{15}$ Mulyasa, Kurikulum Tingkat Satuan Pendidikan. (Bandung: Remaja Rosdakarya, 2009), hlm 153.

${ }^{16}$ Nana Syaodih Sukmadinata, Pengembangan Kurikulum; Teori dan Praktek,

${ }^{17}$ Oemar Hamalik, Dasar-dasar Pengembangan Kurikulum, hlm. 151 hlm 57
} 
sesuai dengan agama dan kepercayaannya masing-masing individu. Dalam kehidupan, dikembangkan sikap saling menghormati dan bekerjasama antara pemeluk-pemeluk agama dan penganut-penganut kepercayaan yang berbedabeda, sehingga dapat terbina kehidupan yang rukun dan damai. ${ }^{18}$

b. Landasan Filsafat. Filsafat pendidikan dipengaruhi oleh dua hal yang pokok, yaitu cita-cita masyarakat dan kebutuhan peserta didik yang hidup di masyarakat. Filsafat adalah cinta pada kebijaksanaan (love of wisdom). Agar seseorang dapat berbuat bijak, maka harus berpengetahuan, pengetahuan tersebut diperoleh melalui proses berpikir secara sistematis, logis dan mendalam. Filsafat dipandang sebagai induk segala ilmu karena filsafat mencakup keseluruhan pengetahuan manusia yaitu meliputi metafisika, epistimologi, aksiologi, etika, estetika, dan logika. ${ }^{19}$

c. Landasan Psikologi Belajar. Kurikulum belajar mengetengahkan beberapa teori belajar yang masing-masing menelaah proses mental dan intelektual perbuatan belajar tersebut. Kurikulum yang dikembangkan sebaiknya selaras dengan proses belajar yang dilakukan oleh siswa sehingga proses belajarnya terarah dengan baik dan tepat. $^{20}$

d. Landasan Sosio-budaya. Nilai sosial-budaya dalam masyarakat bersumber dari hasil karya akal budi manusia, sehingga dalam menerima, menyebarluaskan, dan melestarikannya manusia menggunakan akalnya. Setiap masyarakat memiliki adat istiadat, aturan-aturan, dan cita-cita yang ingin dicapai dan dikembangkan. Dengan adanya kurikulum di madrasah diharapkan pendidikan dapat memperhatikan dan merespon hal-hal tersebut. ${ }^{21}$

e. Landasan Perkembangan Ilmu Pengetahuan dan Teknologi. Pendidikan merupakan suatu usaha penyiapan peserta didik untuk menghadapi lingkungan hidup yang mengalami perubahan yang semakin pesat dan terus berkembang. Sehingga dengan bekal ilmu pengetahuan dan teknologi, setelah siswa lulus diharapkan dapat menyesuaikan diri di lingkungannya dengan baik. ${ }^{22}$

${ }^{18}$ Oemar Hamalik, Dasar-dasar Pengembangan Kurikulum, ........, hlm. 68

19 Muhammad Zaini, Pengembangan Kurikulum Konsep Implementasi Evaluasi dan Inovasi. (Yogyakarta: Teras, 2009), hlm 23

${ }^{20}$ Oemar Hamalik, Dasar-dasar Pengembangan Kurikulum, ........., hlm 58

${ }^{21}$ Syaiful Sagala, Konsep dan makna Pembelajaran. (Bandung: Alfabeta, 2010), hlm 250

22 Oemar Hamalik, Kurikulum dan Pembelajaran. (Jakarta: Bumi Aksara, 2001), hlm 22-23 


\section{B. Model Pengembangan Kurikulum}

Banyak model yang dapat digunakan dalam pengembangan kurikulum. Pemilihan suatu model pengembangan kurikulum bukan saja didasarkan atas kelebihan dan kebaikan-kebaikannya serta kemungkinan pencapaian hasil yang optimal, tetapi juga perlu disesuaikan dengan sistem pendidikan dan sistem pengelolaan pendidikan yang dianut serta model konsep pendidikan mana yang digunakan. Model pengembangan kurikulum dalam sistem pendidikan dan pengelolaan yang sifatnya sentralisasi berbeda dengan yang desentralisasi. Begitu juga dengan kurikulum yang sifatnya subjek akademis akan berbeda dengan kurikulum humanistik, teknologis maupun rekonstruksi sosial.

Sekurang-kurangnya dikenal tujuh model pengembangan kurikulum, yaitu: the administrative (line staff) model, the grass roots model, Beauchamp's system, the demonstrartion model, Taba's inverted model, Roger's interpersonal relations model dan the systematic action research model.

\section{The administrative (line staff) model}

Ada beberapa istilah yang digunakan untuk pengembangan kurikulum model Administratif, antara lain yaitu: top down approach dan line staf procedure. Semuanya memiliki arti yang sama yaitu suatu pendekatan atau prosedur pengembangan kurikulum yang dilakukan oleh suatu tim atau para pejabat tingkat atas sebagai pemilik kebijakan. ${ }^{23}$ Secara teknis operasional pengembangan kurikulum model administratif ini adalah sebagai berikut:

a. Tim pengembangan kurikulum mulai mengembangkan konsep-konsep umum, landasan, rujukan maupun strategi naskah akademik

b. Analisis kebutuhan

c. Secara operasional mulai merumuskan kurikulum secara komprehensif

d. Kurikulum yang sudah selesai dibuat kemudian dilakukan uji validasi dengan cara melakukan uji coba dan pengkajian secara lebih cermat oleh tim pengarah tenaga ahli

e. Revisi berdasarkan pada masukan yang diperoleh

f. Sosialisasi dan desiminasi

${ }^{23}$ Nana Syaodih Sukmadinata, Pengembangan Kurikulum teori dan Praktek, ........, hlm. 161 
g. Monitoring dan evaluasi. ${ }^{24}$

Lebih jelas tahap-tahap pengembangan kurikulum tersebut di atas dapat digambarkan dalam bagan sebagai berikut:

Tim Penyusun

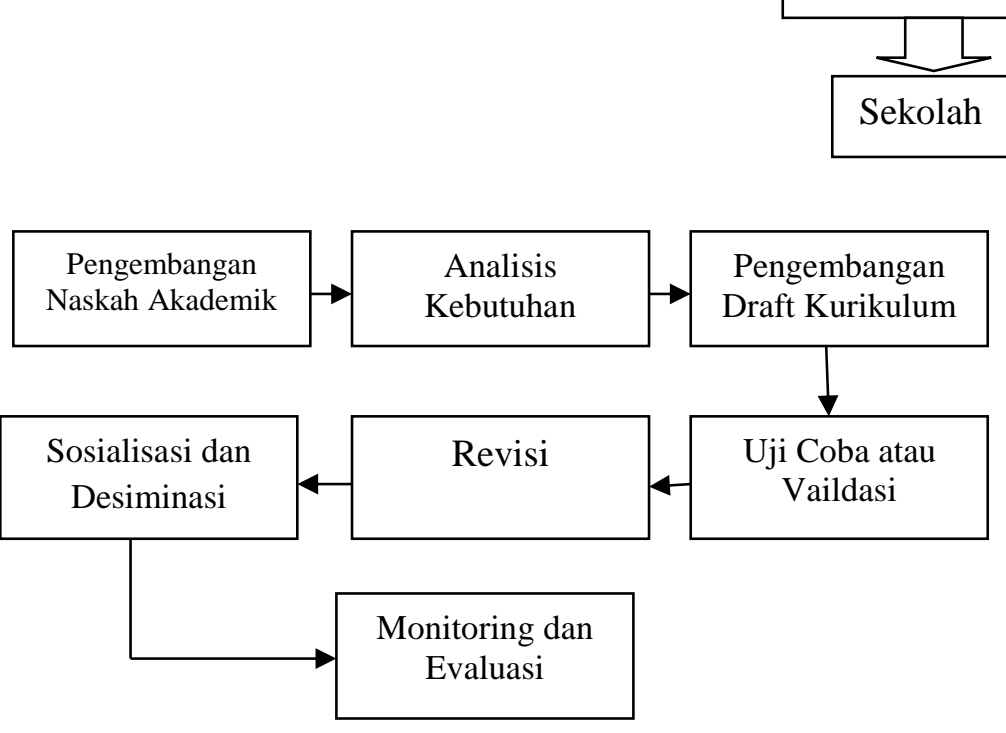

\section{The grass roots model}

Pendekatan Grass roots merupakan kebalikan dari pendekatan administratif. Pendekatan grass roots disebut juga dengan istilah pendekatan bottom-up, yaitu suatu proses pengembangan kurikulum yang diawali dari keinginan yang muncul dari tingkat bawah sekolah atau guru.

Keinginan ini biasanya didorong oleh hasil pengalaman yang dirasakan pihak sekolah atau guru, di mana kurikulum yang sedang berjalan dirasakan terdapat beberapa masalah atau ketidaksesuaian dengan kebutuhan dan potensi yang tersedia di lapangan. Untuk terlaksananya pengembangan kurikulum model grass roots ini diperlukan kepedulian dan profesionalisme yang tinggi dari pihak sekolah antara lain yaitu:

a. Sekolah atau guru bersifat kritis untuk menyikapi terhadap kurikulum yang sedang berjalan

\footnotetext{
${ }^{24}$ Dakir, Perencanaan Dan Pengembangan Kurikulum, ......., hlm. 105
} 
b. Sekolah atau guru memiliki ide-ide inovatif dan bertanggung jawab untuk mengembangkan kurikulum yang sesuai dengan kebutuhan dan potensi yang dimiliki

c. Sekolah atau guru secara terus menerus terlibat dalam proses pengembangan kurikulum

d. Sekolah atau guru bersikap terbuka dan akomodatif untuk menerima masukan-masukan dalam rangka pengembangan kurikulum. ${ }^{25}$

Pengembangan kurikulum model grass roots ini secara teknis operasional bisa dilakukan dalam pengembangan kurikulum secara menyeluruh (kurikulum utuh), maupun pengembangan hanya terhadap aspek-aspek tertentu saja. Misalnya pengembangan untuk satu mata pelajaran atau kelompok mata pelajaran tertentu, pengembangan terhadap metode dan strategi pembelajaran, pengembangan visi dan misi serta tujuan, dan lain sebagainya. Dengan demikian yang dimaksud pengembangan kurikulum baik dengan pendekatan top down approach maupun grass roots approach secara teknis bisa dilakukan terhadap kurikulum secara menyeluruh (kurikulum utuh), atau hanya berkenaan dengan bagian atau aspek-aspek tertentu saja sesuai dengan kebutuhan.

Adapun perbedaan yang sangat mendasar bahwa pendekatan grass roots, inisiatif perbaikan dan penyempurnaan muncul dari arus bawah (sekolah atau guru) seperti tertera pada tanda panah diatas ini. Adapun tahap-tahap yang dilakukan ketika mengembangkan kurikulum dengan menggunakan pendekatan grass roots, yaitu seperti bagan berikut:

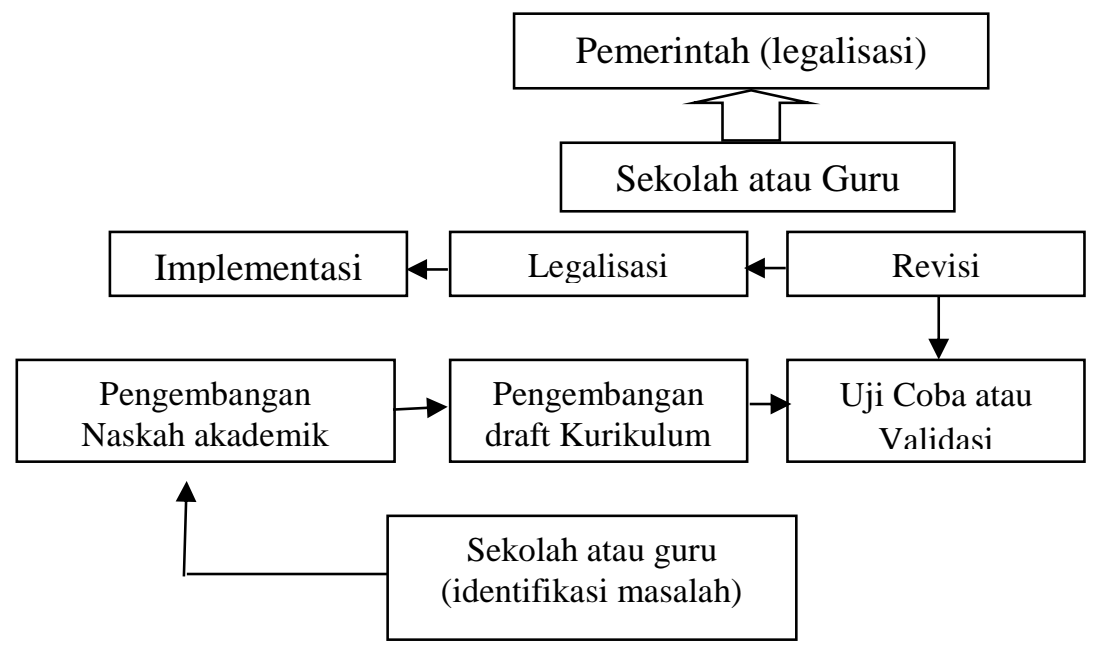

${ }^{25}$ Dakir, Perencanaan Dan Pengembangan Kurikulum, , hlm. 105 


\section{Beauchamp's system}

Pengembangan kurikulum dengan menggunakan metode beauchamp dikembangkan oleh Beauchamp, seorang ahli dibidang kurikulum, yang memiliki 5 bagian pembuat keputusan. Lima tahap tersebut adalah:

a. Memutuskan arena atau lingkup wilayah pengembangan kurikulum, merupakan suatu keputusan yang menjabarkan ruang lingkup upaya pengembangan. Misalnya, suatu gagasan pengembangan kurikulum yang telah dilaksanakan di kelas diperluas di sekolah-sekolah di daerah tertentu baik berskala regional atau nasional yang disebut arena.

b. Menetapkan personalia atau tim para ahli kurikulum, yaitu siapa-siapa saja yang ikut terlibat dalam pengembangan kurikulum.

c. Tim pengembang menyusun tujuan pengajaran kurikulum dan pelaksanaan proses belajar mengajar, untuk tugas tersebut perlu dibentuk dewan kurikulum sebagai koordinator yang bertugas juga sebagai penilai pelaksanaan kurikulum, memilih materi pelajaran baru, menentukan berbagai kriteria untuk memilih kurikulum mana yang akan dipakai dan menulis secara menyeluruh mengenai kurikulum yang akan dikembangkan.

d. Implementasi kurikulum, yakni kegiatan untuk menerapkan kurikulum seperti yang sudah diputuskan dalam ruang lingkup pengembangan kurikulum.

e. Evaluasi kurikulum. ${ }^{26}$

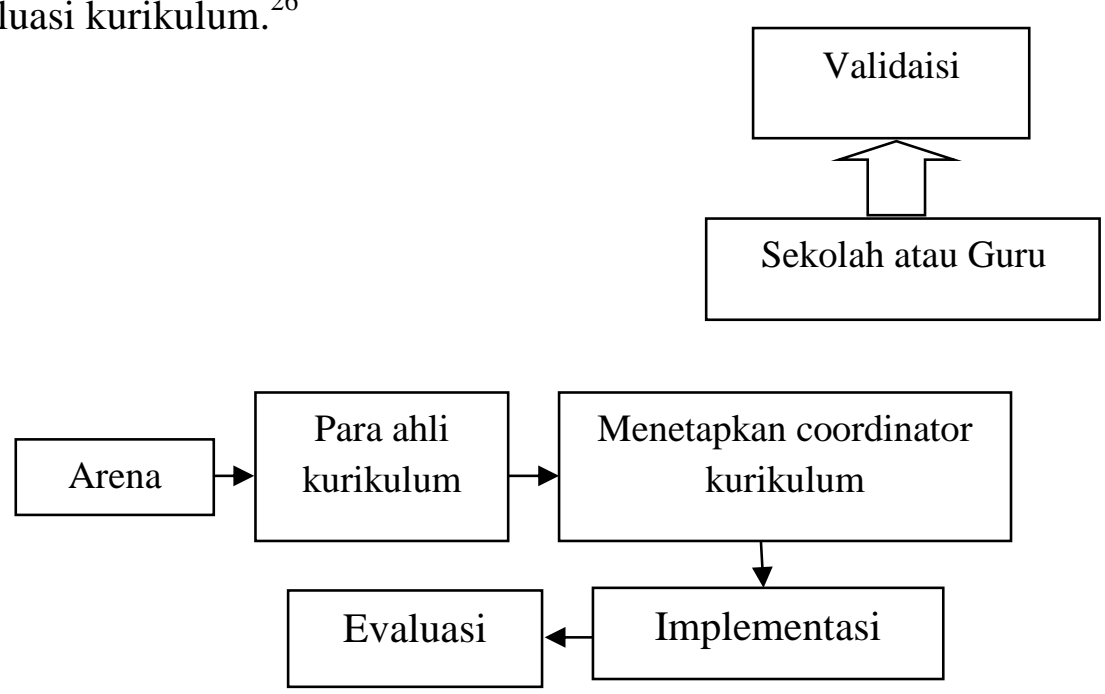

${ }^{26}$ Nana Syaodih Sukmadinata, Pengembangan Kurikulum teori dan Praktek, ........, hlm. 163 


\section{The demonstrartion model}

Model demonstrasi pada dasarnya bersifat grass-roots, datang dari bawah. Model ini diprakarsai oleh sekelompok guru atau sekelompok guru bekerja sama dengan ahli yang bermaksud mengadakan perbaikan kurikulum. Model ini umumnya berskala kecil, hanya mencakup satu atau beberapa sekolah, satu komponen kurikulum atau mencakup keseluruhan komponen kurikulum. Ciri-ciri model demonstrasi ini adalah:

a. Sekelompok guru dari satu sekolah atau beberapa sekolah ditunjuk untuk melaksanakan suatu percobaan tentang pengembangan kurikulum.

b. Kemudian hasilnya disebarluaskan di sekolah sekitar.

\section{Taba's inverted model}

Model pengembangan kurikulum ini dikembangkan oleh Hilda Taba atas dasar data induktif yang disebut model terbalik, karena biasanya pengembangan kurikulum didahului oleh konsep-konsep yang secara deduktif. Taba berpendapat model deduktif ini kurang cocok, sebab tidak merangsang timbulnya inovasi-inovasi, menurutnya pengembangan kurikulum yang lebih mendorong inovasi dan kreatiitas guru adalah yang bersifat induktif, yang merupakan investasi atau arahan terbalik dari model tradisional. $^{27}$

Pengembangan model ini diawali dengan melakukan pencarian data serta percobaan dan penyusunan teori serta diikuti dengan tahapan implementasi, hal ini dilakukan guna mempertemukan teori dan praktek, adapun lankah -langkahnya adalah:

a. Mendiagnosis kebutuhan merumuskan tujuan menentukan materi, penilaan, memperhatikan antara luas dan dalamnya bahan, kemudian disusunkah suatu unit kurikulum.

b. Mengadakan try out

c. Mengadakan revisi atas tray out

d. Menyusun kerangka kerja teori

${ }^{27}$ Nana Syaodih Sukmadinata, Pengembangan Kurikulum teori dan Praktek, ........, hlm. 167 
e. Mengumumkan adanya kurikulum baru yang akan diterapkan. ${ }^{28}$

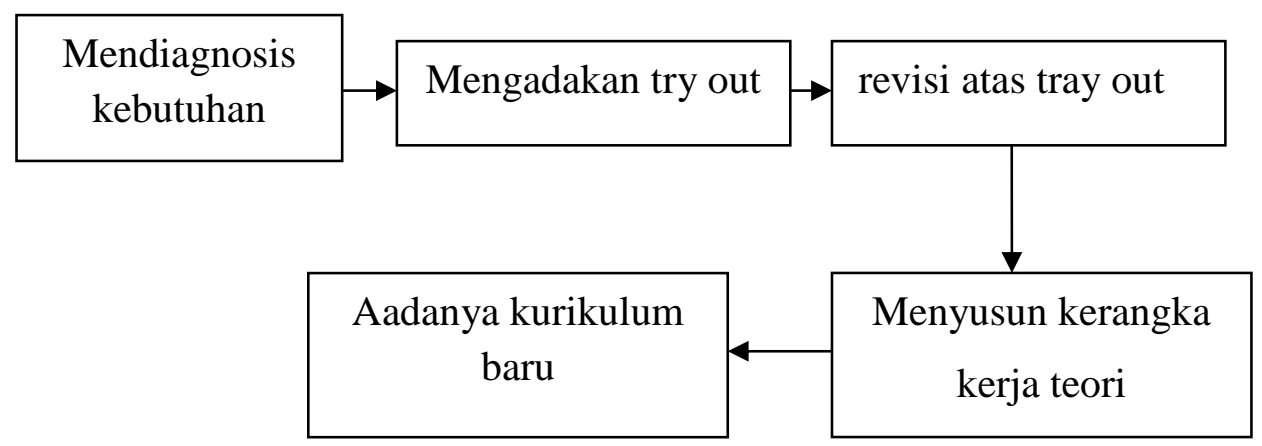

\section{Roger's interpersonal relations model}

Carl Rogers adalah seorang ahli psikologi yang berpandangan bahwa manusia dalam proses perubahan mempunyai kekuatan dan potensi untuk berkembang sendiri tetapi karena ada hambatan-hambatan tertentu ia membutuhkan orang lain untuk mempercepat perubahan tersebut. ${ }^{29}$ Berdasarkan pandangan tentang manusia maka Rogers mengemukakan model pengembangan kurikulum yang disebut dengan model Relasi Interpersonal Rogers. Ada empat langkah pengembangan kurikulum model Rogers diantaranya adalah:

a. Diadakan kelompok untuk dapat melakukan hubungan interpersonal di tempat yang tidak sibuk untuk memilih target sistem pendidikan.

b. Pengalaman kelompok yang intensif bagi guru, atau dalam waktu tertentu para peserta saling bertukar pengalaman di bawah pimpinan staf pengajar.

c. Kemudian diadakan pertemuan dengan masyarakat yang lebih luas lagi dalam suatu sekolah, sehingga hubungan interpersonal akan lebih sempurna yaitu antara guru dengan murid, guru dan peserta didik dan lainnya.

d. Selanjutnya diadakan pertemuan dengan masyarakat yang lebih luas lagi seperti langkah no 3 dalam situasi ini diharapkan masing-masing person akan saling menghayati dan lebih akrab sehingga memudahkan memecahkan masalah sekolah lebih cepat.

${ }^{28}$ H. Dakir, Perencanaan Dan Pengembangan Kurikulum, ......., hlm. 107

${ }^{29}$ Nana Syaodih Sukmadinata, Pengembangan Kurikulum teori dan Praktek, ........, hlm. 167 


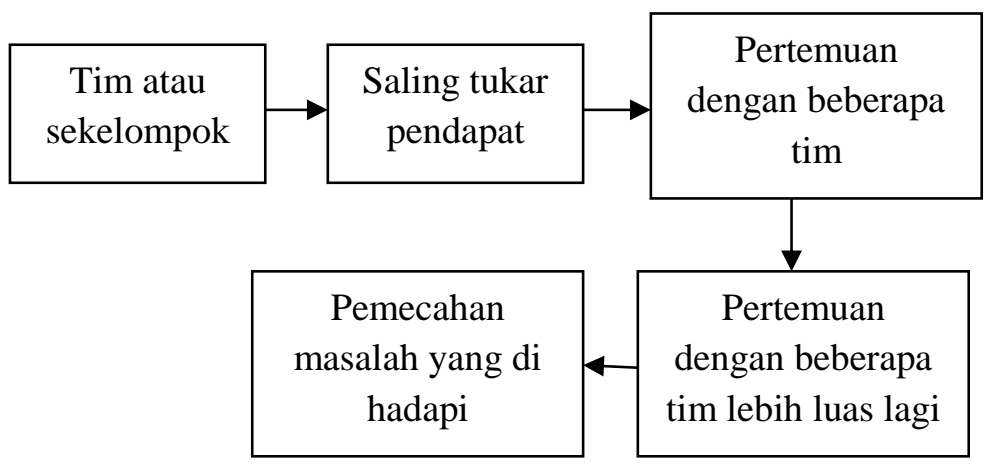

\section{The systematic action research model}

Model ini dikenal juga dengan nama action research model dengan asumsi bahwa perkembangan kurikulum merupakan perubahan sosial. Dari sisi proses, kurikulum model ini sudah melibatkan seluruh komponen pendidikan yang meliputi siswa, orang tua, guru serta sistem sekolah. Kurikulum dikembangkan dalam rangka memenuhi kebutuhan para pemangku kepentingan (stakeholder) yang meliputi orang tua siswa, masyarakat, dan lain-lain. Penyusunan kurikulum dilakukan dengan mengikuti prosedur action research. ${ }^{30}$ Ada dua langkah dalam penyusunan kurikulum jenis ini:

a. Melakukan kajian tentang data-data yang dikumpulkan sebagai bahan penyusunan kurikulum. Data (informasi) yang dikumpulkan hendaknya valid dan reliabel sehingga dapat digunakan sebagai dasar yang kuat dalam pengambilan keputusan penyusunan kurikulum. Data yang lemah akan mengakibatkan kesalahan dalam pengambilan keputusan. Berdasarkan keputusan ini, disusunlah rencana yang menyeluruh (komprehensif) tentang cara-cara mengatasi masalah yang ada.

b. Melakukan implementasi atas keputusan yang dihasilkan pada langkah pertama. Dari proses ini akan diperoleh data-data (informasi) baru yang selanjutnya dimanfaatkan untuk mengevaluasi masalah-masalah yang muncul dilapangan sebagai upaya tindak lanjut untuk memodifikasi atau memperbaiki kurikulum.

${ }^{30}$ Sukmadinata, Nana Syaodih, Pengembangan Kurikum Teori dan Praktek, (Bandung: P.T. Remaja Rosdakarya 2005) Hlm 169. 


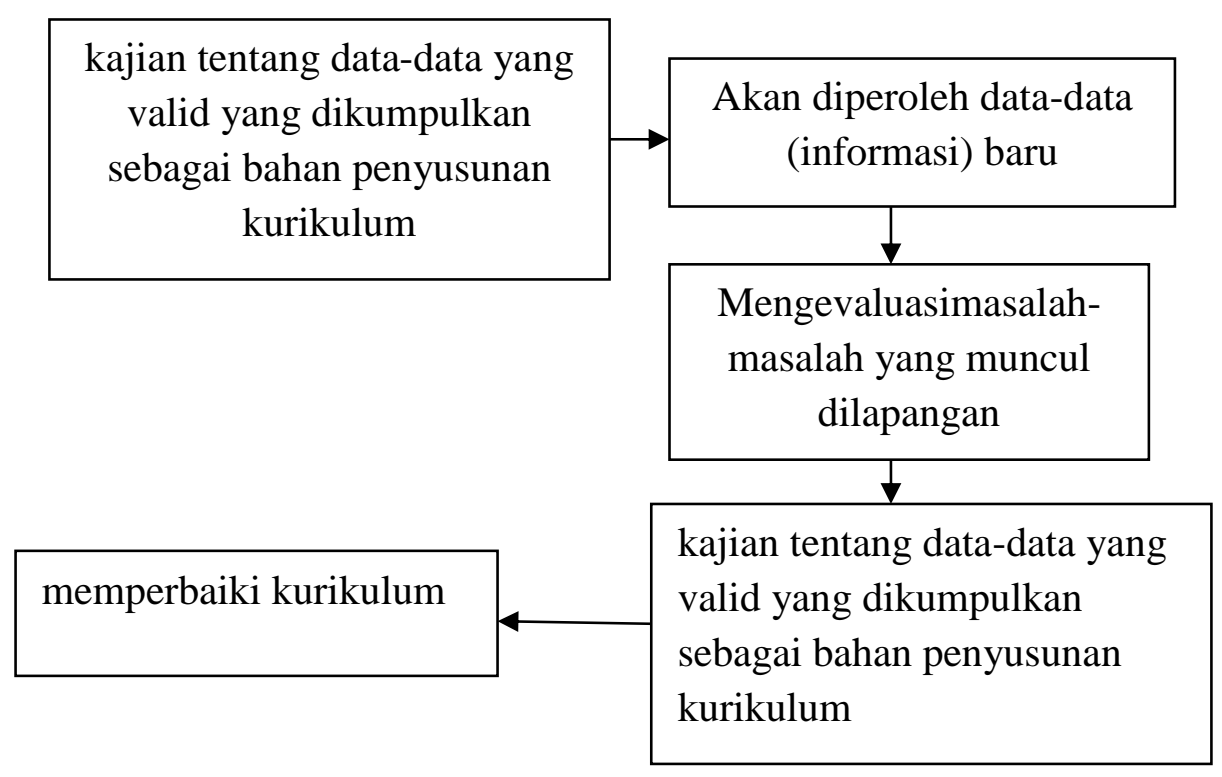

\section{Prosedur Pengembangan Kurikulum di Madrasah}

Setelah kita memahami pengertian dan model-model pengembangan kurikulum, kita tinggal menerapkan konsep pengembangan kurikulum tersebut. Akan tetapi, penerapan tersebut haruslah melalui beberapa prosedur. Prosedur yang sistematis ini saling terkait dan berkelanjutan atau bisa dikatakan berdasarkan pada proses manajeman. Adapun prosedurnya yaitu; perencanaan kurikulum, pengorganisasian kurikulum, penyusunan staf dan kontrol kurikulum. ${ }^{31}$

\section{a. Perencanaan Kurikulum}

Perencanaan merupakan suatu proses intelektual yang melibatkan pembuatan keputusan. Proses ini menuntut persiapan mental untuk berpikir sebelum bertindak, berbuat berdasarkan kenyataan, bukan perkiraan dan berbuat sesuatu secara teratur. Perencanaan membantu organisasi untuk fokus pada keuntungan jangka pendek untuk mempertimbangkan pentingnya program dan kegiatan-kegiatan serta pengaruhnya untuk masa mendatang. Suatu rencana yang baik terdiri dari 5 unsur khusus, yaitu:

1) Tujuan dirumuskan secara jelas.

2) Komperhensif, menyeluruh namun jelas bagi staf dan para anggota organisasi.

3) Hirarki rencana yang terfokus pada daerah yang paling penting.

4) Bersifat ekonomis, mempertimbangkan sumber-sumber yang tersedia.

5) Layak, yaitu memungkinkan adanya perubahan.

\footnotetext{
${ }^{31}$ Oemar Hamalik, Manajemen Pengembangan Kurikulum, (Bandung: Remaja Rosdakarya, 2006), hal. 135139.
} 


\section{b. Pengorganisasian Kurikulum}

Organisasi adalah suatu kelompok sosial yang bersifat tertutup atau terbuka terhadap pihak luar yang diatur berdasarkan aturan tertentu yang dipimpin oleh seorang pemimpin atau seorang staf administratif yang dapat melaksanakan bimbingan secara teratur dan bertujuan. Untuk mengembangkan kurikulum, pengorganisasiannya adalah:

1) Organisasi perencanaan kurikulum, dilaksanakan oleh suatu tim pengembang kurikulum.

2) Organisasi dalam rangka pelaksanaam kurikulum, pada tingkat daerah atau

3) Organisasi dalam evaluasi kurikulum, yang melibatkan berbagai pihak yang berkepentingan.

Pada masing-masing jenis organisasi tersebut dilaksanakan oleh suatu susunan kepengurusan yang ditentukan sesuai dengan struktur organisasi dengan tugas-tugas ornganisasi tertentu. Secara akademik, organisai kurikulumnya meliputi:

1) Kurikulum mata pelajaran, terdiri dari sejumlah mata pelajaran secara terpisah.

2) Kurikulum bidang studi, memfungsikan beberapa mata pelajaran sejenis.

3) Kurilukulum integrasi, memusatkan kurikulum pada opik atau masalah tertentu.

4) Core Curcuum, kurikum disusun berdasarkan masalah dan kebutuhan siswa.

5) Di sini, bentuk-betuk kurikulum disusun menurut pola organisasi kurikulum yang terstruktur, urutan dan ruang lingkup materi tertentu.

\section{c. Penyusunan Staf}

Staffing adalah fungsi yang menyediakan orang-oang untuk melaksanakan suatu sistem yang direncanakan dan diorganisasikan. Staffing dilaksanakan setelah semua tugas ditetapkan terlebih dahulu. Staffing terdiri dari:

1) Rekruitmen; adalah suatu proses ketenagaan yang berkualifikasi tertentu untuk menempati posisi kerja yang tersedia. Rekrutmen ini bisa dilaksanakan secara internal dan eksternal. 
2) Seleksi; adalah proses mengidentifikasi kriteria seleksi bagi calon ketenagaan.

3) Hiring; setelah mengidentifikasi kandidat-kandidat terbaik, kemudian perlu dipilih kandidat yang paling baik dari daftar tersebut, menentukan calon yang paling memenuhi kualifikasi yang telah ditetapkan.

4) Penempatan; proses ini merupakan ke lingkungan pekerjaan yang senyatanya. Disini, tenaga kerja diberikan kesempatan untuk mengembangkan bakatnya secara maksimal.

5) Manajemen staf; adalah kegiatan menumbuhkan dan mengembangkan unsur ketenagaan pada suatu lembaga.

\section{d. Kontrol Kurikulum}

Pengontrolan adalah proses pengecekan performance terhadap standart untuk menentukan sejauh mana tujuan telah tercapai. Kontrol ini sangat berhubungan erat dengan perencanaan sebagai bagian dari sistem. Sedangkan control kurikulum adalah proses pembuatan beberapa keputusan tentang kurikulum di dalam sekolah, atau proses pengajaran yanag dibatasi oleh minatminat pihak luar, seperti orang tua, karyawan dan masyarakat.

\section{Implementasi Kurikulum 2013 di Madrasah}

Implementasi merupakan proses penerapan ide, konsep, kebijakan, dalam bentuk tindakan praktis, sehingga memberikan dampak, baik berupa perubahan pengetahuan, keterampilan, maupun nilai dan sikap. ${ }^{32}$ Sehingga implementasi kurikulum adalah bagian yang paling menentukan dalam siklus kurikulum. Ini karena seringkali kegagalan kebijakan pendidikan yang menyangkut kurikulum terjadi bukan karena tidak tepatnya kebijakan yang dikeluarkan, melainkan implementasinya yang tidak tepat. Oleh karena itu, sebaik apapun kurikulum dirumuskan, tentu tidak akan bermakna apapun bila implementasinya tidak sesuai dengan yang direncanakan.

Miller dan Seller mengidentifikasi tiga makna implementasi yang umum dipahami. Pertama, implementasi adalah sebuah proses di mana guru menggunakan kurikulum baru di saat mereka mengajar. Kedua, implementasi adalah sebuah proses interaksi antara pembuat kurikulum dan guru (jika kurikulum

${ }^{32}$ Musthofa Rembangy, Pendidikan Transformatif, (Yogyakarta : Teras, 2008), hlm. 131. 
tidak dibuat sendiri oleh guru). Dalam interaksi ini terjadi dialog antara pembuat kurikulum dan guru sebagai pelaksana kurikulum di lapangan. Keduanya memastikan bagaimana kurikulum yang telah direncanakan dapat diterapkan secara tepat dengan mempertimbangkan keadaan setempat. Ketiga, implementasi dianggap sebagai sebuah bagian tersendiri dari siklus kurikulum yang perlu direncanakan dan diorganisasikan secara khusus. ${ }^{33}$

Saat ini implementasi kurikulum 2013 sudah berjalan di hampir semua sekolah, tak terkecuali madrasah. Implementasi kurikulum 2013 ini diharapkan dapat menghasilkan insan Indonesia yang produktif, kreatif, inovatif dan aktif melalui penguatan dari KBK 2004 dan KTSP 2006 yang mempertimbangkan penataan pola pikir dan tata kelola, pendalaman dan perluasan materi, serta penguatan proses dan penyesuaian beban belajar, serta yang paling penting kuncinya ada di tangan guru. Pemerintah melalui Kementerian Pendidikan dan Kebudayaan (Kemendikbud) telah memberlakukan implementasi kurikulum 2013 pada tahun pelajaran 2013/ 2014 untuk sebagian sekolah umum. Sementara untuk madrasah, berangkat dari Surat Edaran yang ditandatangi Dirjen Pendis bernomor SE/Dj.I/PP.00/50/2013 implementasi kurikulum 2013 pada Madrasah Ibtidaiyah (MI), Madrasah Tsanawiyah (MTs) dan Madrasah Aliyah (MA) dimulai pada tahun pelajaran 2014/ 2015, yang akan diterapkan pada tingkat MI di kelas I dan IV, tingkat MTs kelas VII dan tingkat MA kelas X.

Perubahan Kurikulum 2006 menjadi Kurikulum 2013 pada dasarnya adalah perubahan pola pikir (mindset) guru, secara spesifik dapat dikatakan merupakan perubahan budaya dan iklim mengajar dari para guru serta belajar dari peserta didik dalam melaksanakan pendidikan di sekolah/ madrasah mulai dari proses pembelajaran sampai sistem penilaian yang diterapkan. Secara fundamental kurikulum 2013 hanya ingin mengubah orientasi pembelajaran dari yang selalu mengukur kemampuan akademis siswa (kognitif) menjadi berorientasi pada pengembangan sikap dan keterampilan dasar, kenyataannya masih banyak madrasah yang kurikulum memakai k13 akan tetapi pembelajarannya masih konvensional dan masih berfokus pada kognitif siswa. Tentu melihat kondisi seperti ini dibutuhkan strategi pengembangan mutu guru madrasah secara

${ }^{33}$ J. P. Miller and W. Seller, Curriculum: Perspective and Practice, (New York: Longman, 1985), hlm. 246247 
terencana, terukur dan terarah, sebab kalau tidak, akan berdampak terhadap pencapaian mutu, relevansi dan citra madrasah ke depan.

\section{Kesimpulan}

Berdasarkan latar belakang dan pembahasan di atas, dapat ditarik kesimpulan sebagai berikut:

1. Manajemen pengembangan kurikulum merupakan prosedur umum dalam kegiatan mendesain (designing), menerapkan (implementation), dan mengevaluasi (evaluation) suatu kurikulum. Dalam manajemen pengembangan kurikulum di Madrasah pihak-pihak yang harus berpartisipasi diantaranya harus memahami prinsip dan landasan pengembangan kurikulum, serta mengetahui model pengembangan kurikulum yang akan diterapkan.

2. Secara fundamental kurikulum 2013 hanya ingin mengubah orientasi pembelajaran dari yang selalu mengukur kemampuan akademis siswa (kognitif) menjadi berorientasi pada pengembangan sikap dan keterampilan dasar. Kenyataan dilapangan masih ditemukan guru yang mengajar dengan sistem konvensional meskipun madrasah tersebut telah menggunakan K13.

\section{DAFTAR PUSTAKA}

H. Dakir. 2004. Perencanaan dan Pengembangan Kurikulum. Jakarta: PT Rineka Cipta

Hamalik, Oemar. 2001. Kurikulum dan Pembelajaran. Bandung: Bumi Aksara

Hamalik, Oemar. 2006. Manajemen Pengembangan Kurikulum. Bandung: Remaja Rosdakarya

Hamalik, Oemar. 2013. Dasar-dasar Pengembangan Kurikulum. Bandung: PT Remaja Rosdakarya

http://www.bintangbangsaku.com/content/prinsip-prinsip-pengembangan-kurikulumtingkat-satuan-pendidikan, diakses pada tanggal 21 Mei 2018

J. P. Miller and W. Seller. 1985. Curriculum: Perspective and Practice. New York: Longman

Muhaimin dkk. 2005. Pengembangan Kurikulum Berbasis Kompetensi di Perguruan Tinggi Agama Islam. Yogyakarta: Pustaka Pelajar 
Muhaimin dkk. 2008. Pengembangan Model Kurikulum Tingkat Satuan Pendidikan (KTSP) pada Sekolah dan Madrasah. Jakarta: Rajawali Pers

Mulyasa. 2009. Kurikulum Tingkat Satuan Pendidikan. Bandung: Remaja Rosdakarya Ramayulis. 2008. Ilmu Pendidikan Islam. Jakarta: Kalam Mulia

Rembangy, Musthofa. 2008. Pendidikan Transformatif. Yogyakarta: Teras

Sagala, Syaiful. 2010. Konsep dan makna Pembelajaran. Bandung: Alfabeta

Sukmadinata, Nana Syaodih. 2007. Pengembangan Kurikulum teori dan Praktek. Bandung: PT Remaja Rosda Karya

Suparlan. 2011. Tanya Jawab Pengembangan Kurikulum dan Materi Pembelajaran. Jakarta: Bumi Aksara

UU No. 20 tahun 2003 Sistem Pendidikan Nasional. Jakarta

W. H. Schubert. 1986. Curriculum: Perspective, Paradigm and Possibility. New York: MacMillan

Zaini, Muhammad. 2009. Pengembangan Kurikulum Konsep Implementasi Evaluasi dan Inovasi. Yogyakarta: Teras 